\title{
THE EFFECTS OF NITROGEN AND CARBON DIOXIDE GASES IN REDUCING THE PRICKLING AND TINGLING SENSATIONS IN FRESH-CUT PINEAPPLE (Ananas comosus L cv. Morris)
}

\author{
AIDA NADIA A.RAMLEE AND WAN ZALIHA WAN SEMBOK*
}

Faculty of Fisheries and Food Science, Universiti Malaysia Terengganu, 21030 Kuala Nerus, Terengganu, Malaysia.

*Corresponding author: wzaliha@umt.edu.my

http://doi.org/10.46754/umtjur.2021.04.002

\begin{abstract}
Fresh-cut pineapple has experienced an increase in demand due to its great health benefits and is rich in vitamins A, B and C. Moreover, pineapple is known as a source of the enzyme bromelain, which has therapeutic applications, such as reducing inflammation, improving digestion and treating osteoarthritis. However, bromelain generally affects the pineapple's flavour and is less preferred by consumers due to the uncomfortable prickling and tingling sensations it brings. In the present study, two types of gases and their combination, nitrogen $\left(\mathrm{N}_{2}\right)$ and carbon dioxide $\left(\mathrm{CO}_{2}\right)$, were used to evaluate their impacts on reducing the tingling and prickling sensations, as well as maintaining the postharvest qualities of fresh-cut pineapple stored at $5^{\circ} \mathrm{C}$ for 12 days. The parameters being evaluated were the bromelain enzyme activity, flesh colour, ascorbic acid concentration, flesh firmness, soluble solids concentration (SSC), titratable acidity (TA) and sensory evaluation. No significant differences were recorded for all parameters tested. Based on the sensory evaluations, all the attributes, such as colour, aroma, texture, sweetness, sourness, tingling and prickling sensations, and overall acceptance were not affected by the different gases application. Even though no apparent effect was observed, the 30 panellists preferred the aforementioned attributes, except sourness. In conclusion, the fumigation treatments with $\mathrm{N}_{2}$ and $\mathrm{CO}_{2}$ gases were not effective in reducing the tingling and prickling sensations of pineapples cv. Morris.
\end{abstract}

Keywords: Prickling, tingling, organoleptic, postharvest, quality

\section{Introduction}

The pineapple (Ananas comosus L.) belongs to the Bromeliaceae family and is commonly cultivated in most tropical and subtropical countries, including Malaysia (Carlier, et al., 2010; Avallone et al., 2003). In Malaysia, pineapples are mostly cultivated in Johor because of the enriched peat soil, which is suitable for their growth. It has been reported that 15,649 hectares of land in Malaysia is planted with pineapples, with the total production estimated at 355,000 metric tonnes (Thalip et al., 2015). Fresh pineapple contributes $70 \%$ and $3 \%$ of the total production for the local and export markets, respectively. Meanwhile, $95 \%$ of canned pineapple productions are for the export market, and the remaining $5 \%$ is for the domestic market (Malaysian Pineapple Industry Board, 2018). The modern lifestyle and purchase behaviour of ready-to-eat food could be another reason for the increasing demand for pineapple locally and globally. In Malaysia, there are many pineapple cultivars available, such as N36, Maspine, Morris Bentanggur, MD2, Morris Gajah, Gandul, Sarawak Green Local, Josapine, and Yankee (Hidayat et al., 2012).

Pineapple is consumed in many parts of the world as fresh fruit, juice, jam, jelly and dried products. Pineapple contains an important proteolytic enzyme, bromelain, which acts as anti-inflammatory agent, modulates tumor growth and blood coagulation, improves digestion and treats osteoarthritis, as well as debridement of third-degree burns. Moreover, it is a rich source of vitamins $\mathrm{A}, \mathrm{B}$ and $\mathrm{C}$, as well as several minerals, such as calcium, phosphorus and iron (Yuris \& Siow, 2014). Even though the bromelain enzyme is highly beneficial to human 
health, it sometimes causes an uncomfortable sensation, such as prickling and tingling in the mouth, when consumed. Prickling can be defined as sharp and blunt taste, while tingling is the itching sensation on the tongue. The high content of bromelain in pineapples is less preferred by consumer due to the uncomfortable sensation, such as tenderness to the mouth, including the lips, tongue and cheeks. In addition, bromelain can also cause an allergic reaction to some people (Juan et al., 2015). All these uncomfortable tastes may contribute to a high amount of food losses. In line with that, a suitable postharvest treatment should be conducted to reduce the sensation mentioned above of fresh -cut pineapple, particularly cv. Morris. Currently, there is no report available on reducing the bromelain enzyme activity or concentration in fresh-cut pineapple fruit. Many previous reports focused on reducing the browning and chilling injury symptoms on fresh-cut fruits by using various chemicalbased treatments, such as methyl jasmonate (Gonzalez et al., 2000), salicylic acid (Sayyari et al., 2009), heat treatment (Sayyari et al., 2011), nitric oxide fumigation (Singh et al., 2009), wax edible coating (Qiuping \& Wenshui, 2007) and 1-methylcyclopropene (1-MCP) (Salvador, 2004). Thus, the present study aims to reduce bromelain enzyme activities by the application of physical treatment using nitrogen $\left(\mathrm{N}_{2}\right)$ and carbon dioxide $\left(\mathrm{CO}_{2}\right)$ gases. The mechanism on how these two gases reduce bromelain activity is still unknown. However, these two gases may affect the bromelain enzyme activity by inhibiting the metabolic process during storage by decreasing the reactant and the product of respiration. Therefore, the tingling and prickling sensations could be reduced. However, the exact mechanism on how these uncomfortable sensations could be reduced using these gases warrant further investigation.

\section{Materials and Methods}

\section{Plant Materials and Experimental Design}

A total of 63 pineapples (Ananas comosus L cv. Morris) at maturity index stage 3 were used in the experiment. The pineapples were purchased from Pasar Gong Pauh in Kuala Terengganu. The experiment was conducted at the PostHarvest Technology Laboratory, Faculty of Fisheries and Food Science, Universiti Malaysia Terengganu. The experiment was arranged in a complete randomised design (CRD), with seven treatments, viz. i) $0 \mathrm{~mL}$ gas (serves as control), ii) $15 \mathrm{~mL}$ of $\mathrm{N}_{2}$ gas iii) $25 \mathrm{~mL}$ of $\mathrm{N}_{2}$ gas iv) $15 \mathrm{~mL} \mathrm{CO}_{2}$ gas v) $25 \mathrm{~mL}$ of $\mathrm{CO}_{2}$ gas vi) $15 \mathrm{~mL}$ of $\mathrm{N}_{2}$ and $15 \mathrm{~mL}$ of $\mathrm{CO}_{2}$ gas vii) $25 \mathrm{~mL}$ of $\mathrm{N}_{2}$ and $25 \mathrm{~mL}$ of $\mathrm{CO}_{2}$ gas, with three replications. For each treatment, four pineapple wedges were represented as an experimental unit.

\section{Preparation of Sample and Parameter Evaluations}

A total of 7 plastic containers $(20 \mathrm{~cm} \times 20 \mathrm{~cm})$ were used to place the pineapples wedges. All of the containers, knife, and cutting board were sanitised with $75 \%$ ethanol to avoid contamination to the samples. Then, each pineapple fruit was cut into wedges, $2 \mathrm{~cm}$ thick and $3 \mathrm{~cm}$ long. A total of 24 pineapple wedges were placed inside the plastic containers and sealed tightly using parafilm and cellophane tape to prevent the gas leakage. Next, the assigned $\mathrm{N}_{2}$ and $\mathrm{CO}_{2}$ gases and their combination were immediately injected into the plastic containers through an injection port and left for 20 minutes to enhance uniform absorption of the gas by the pineapple wedges. After 20 minutes, all the pineapple wedges were placed into 168 polystyrene trays, in which each tray consists of four pineapple wedges, and later wrapped using cling wrap. The packaged pineapple wedges were then stored in a chiller at $5^{\circ} \mathrm{C}$ for postharvest quality assessments in threeday intervals, i.e. days $0,3,6,9$ and 12 . The postharvest parameters such as the browning index, total phenolic content, flesh colour, ascorbic acid concentration, flesh firmness, Titratable acidity (TA) and Soluble solids concentration (SSC) were evaluated. The browning index of the fresh-cut pineapple was evaluated visually according to the score given by Ding et al. (2007). The score was given from 
0 to 5 , in which $0=$ none $(0-20 \%$ browning $)$, $1=\operatorname{trace}(20-40 \%$ browning $), 2=\operatorname{slight}(40-60 \%$ browning), $3=$ moderate ( $60-80 \%$ browning), $4=$ severe $(80 \%$ browning) and $5=$ extremely severe (>100\% browning). The flesh colour was measured using the Konica Minolta CR-400 reflectance colorimeter (Minolta camera Co. Ltd., Japan) according to the CIELAB colour parameters: $L^{*}$, chromaticity $\mathrm{a}^{*}$ and chromaticity $b^{*}$ (McGuire, 1992). L* represents the lightness coefficient, which ranges from 0 (black) to 100 (white). $a^{*}$ ranges from -60 to +60 , in which +60 indicates the colour red and -60 indicates the colour green. $b^{*}$ also ranges from -60 to +60 , but +60 represents the colour yellow, while -60 represents the colour blue. The $a^{*}$ and $b^{*}$ values were used to calculate the chroma value $\left[\mathrm{C}^{*}=\right.$ $(a * 2+b * 2) 1 / 2]$ and hue angle $\left(h^{\circ}=\tan -1 b * / a^{*}\right)$. Chroma $\left(\mathrm{C}^{*}\right)$ refers to the colour intensity, while the hue angle represents red-purple $\left(0^{\circ}\right)$, yellow $\left(90^{\circ}\right)$, bluish-green $\left(180^{\circ}\right)$ and blue $\left(270^{\circ}\right)$ angles. The total phenolic content of the fresh-cut pineapple was determined based on the method used by Singleton and Rossi (1965) with a slight modification. The AOAC (2004) method was used to determine the ascorbic acid concentration by using indophenol titration. Flesh firmness was measured using the TA.XT plus texture analyser (Stable Micro Systems, United Kingdom). A probe of $\mathrm{P} / 2$ stainless needle was used to penetrate the flesh of the pineapple with a test speed of $5 \mathrm{~mm} / \mathrm{sec}$ and target distance of $10 \mathrm{~mm}$. The soluble solid concentration was determined using a handheld refractometer, while titratable acidity was measured using the titration method, expressed as $\%$ of citric acid. For the measurement of bromelain enzyme activity, the method used was based on the one used by Mohan et al. (2016). A UV-vis spectrophotometer was used to determine the enzyme activity at $280 \mathrm{~nm}$. Meanwhile, 30 panellists were selected for the sensory evaluation test. The sensory evaluation test of the pineapple was evaluated from the scores given by the panellists. The score given by the panellist were calculated to identify the level of overall acceptance and quality of the fruit (Aisyah et al., 2018)

\section{Statistical analysis}

The data were subjected to the one-way analysis of variance (ANOVA) using the GLM (General Linear Models) procedure with the SAS 9.1 software package, SAS Institute Inc, Cary, NC, USA. Treatment means were further separated by Tukey (HSD) for least significance at $\mathrm{p} \leq 0.05$ (SAS Institute Inc, 1990).

\section{Results and Discussion}

The tingling and prickling sensations in the mouth when consuming pineapple come from the bromelain enzyme, which exists naturally in pineapples fruit. The bromelain enzyme in pineapple is widely known for its benefits in the pharmaceutical and food industries (Bhui, 2009). Even though bromelain in pineapple is beneficial to human health, the tingling and prickling sensations it causes has reduced consumers' decision to purchase the fruit. Among the 7 varieties of pineapple in Malaysia, cv. Morris has been reported to have a high level of bromelain compared with the others. In addition, Morris is normally canned, and not normally used for fresh consumption. In order to increase the demand for Morris among consumer, the tingling and prickling sensations it brings when consumed should be reduced. In the present study, the bromelain activity showed a fluctuating trend throughout 9-day experimental period (Figure 1). On days 0 and 3 , the different gas treatments significantly affected the bromelain enzyme activity. However, the specific trend of the activity could not be deduced throughout the 9-day period. In addition, after day 3 , the enzyme activities were similar among the treatments as no significant results were recorded. Zhan and Zhang (2005) claimed that $\mathrm{N}_{2}$ gas can form gas hydrates after coming into contact with water molecules, which in turn reduces the water activity in fruit tissues and influences the structure of the enzyme. This could be the possible reason for the reduction of enzyme activity, thereby reducing the prickling and tingling sensations. Another reason could be due to the maturity stages of the fruit. As the storage period prolonged, the enzyme activity may also be affected. However, the exact mechanism of how the $\mathrm{N}_{2}$ and $\mathrm{CO}_{2}$ gases affected the prickling and tingling sensations was unknown. Thus, this warrants further investigation. 


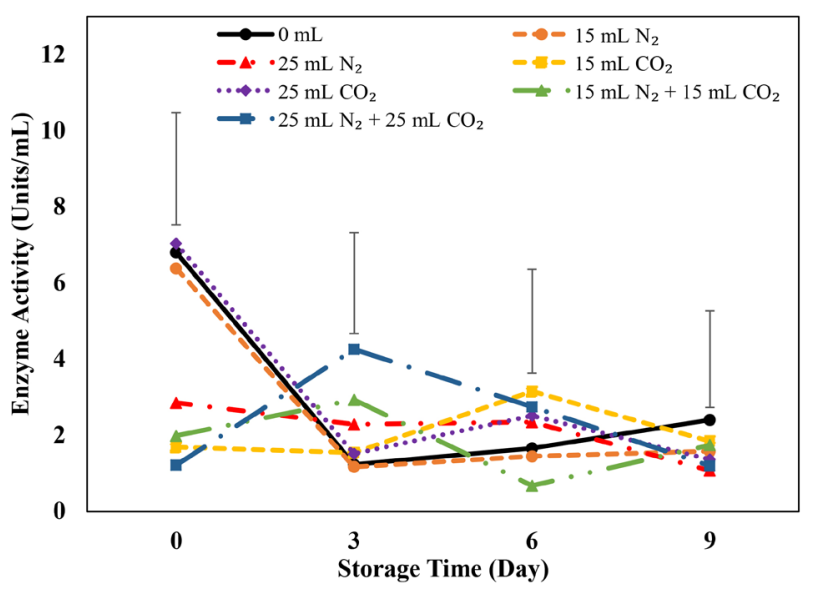

Figure 1: The effects of different volumes of nitrogen and carbon dioxide gases on bromelain enzyme activity of fresh-cut pineapple. The vertical bars represent Tukey at $\mathrm{P} \geq 0.05$. (HSD value $\mathrm{Day} 0=2.9511$, Day3 $=2.6493$, Day6 $=2.7232$, Day9 $=0.71$ )

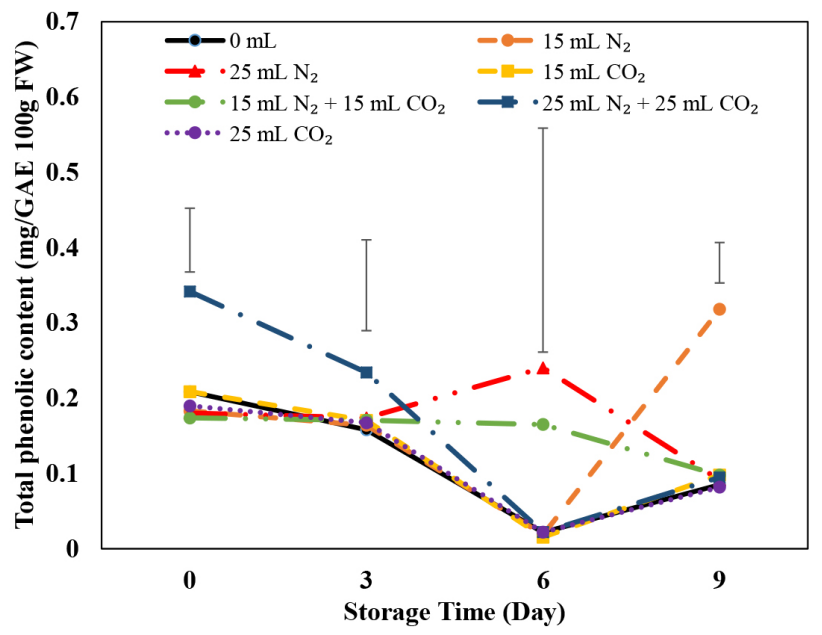

Figure 2: The effect of different volumes of nitrogen and carbon dioxide gases on the total phenolic content of fresh-cut pineapple. The vertical bars represent Tukey at $P \geq 0.05$. (HSD value $D a y 0=0.08$,

Day3 $=0.13$, Day6 $=0.30$, Day9 $=0.05$ )

The different concentrations of $\mathrm{N}_{2}$ and $\mathrm{CO}_{2}$ either alone or in combination resulted in nonsignificant values on the total phenolic content (TPC) after fumigation throughout 9-day storage period. After day 3, the application of $25 \mathrm{~mL}$ of $\mathrm{N}_{2}$ and $25 \mathrm{~mL}$ of $\mathrm{CO}_{2}$ constantly showed a lower TPC after fumigation, compared with other treatments (Figure 2). In contrast, Wan Zaliha and Koh (2016) and Tan et al. (2017) claimed that $25 \% \mathrm{~N}_{2}$ gas maintained and delayed TPC in fresh-cut carambola and pineapple, respectively. Wu et al. (2012) also reported the inhibitory effect of residual $\mathrm{N}_{2}$ gas in microspores of pineapple wedges, which restricted the intracellular enzyme activity related to phenol degradation. They suggested that the TPC decreased with the oxidation of polyphenoloxidase (PPO) in the presence of oxygen, as the tissue senescence 
of pineapple wedges increased. Moreover, Alothman et al. (2010) reported that the decrease in the total phenolic content was due to the exposure time to ozone, which leads to the production of scavenging free radicals, which can initiate their protective roles (Yeoh et al. 2014).

Other postharvest qualities, such as colour, TSS, TA, firmness and ascorbic acid, were not influenced by the gas fumigation. Fruit colour is one of the most important postharvest parameters that usually affects consumer purchase decisions. In this study, fresh-cut pineapple treated with 15 $\mathrm{mL}$ of $\mathrm{N}_{2}$ gas showed high value of lightness coefficient and low value of chromaticity $b^{*}$, compared with other treatments in the 12 days of storage period. It is indicated that high value of $\mathrm{L}^{*}$ and low value of $\mathrm{b}^{*}$ showed the lowest rate of browning incidence (Table 1). Similar results were reported by Tan et al. (2017). They claimed that pineapple treated with $\mathrm{N}_{2}$ gas fumigation maintained the pure yellow colour of the flesh throughout the storage period, with only a very mild browning. Similarly, Gil et al. (1998) suggests that the change in the total phenolic acid of minimally processed lettuce reduced browning when stored in high $\mathrm{CO}_{2}$ levels. In contrast, low values of $\mathrm{L}^{*}$ and high values of $b^{*}$ indicate the severity of browning incidence and darken the surface colour. The severity of browning incidence can be seen in fresh-cut pineapple treated with $15 \mathrm{~mL}$ of $\mathrm{N}_{2}$ and $\mathrm{CO}_{2}$. A study suggests that the change of colour in tomato, in which the skin and pulp increased in redness during storage, is closely related to the percentage weight loss caused by the dehydration process throughout the storage period (Khairi et al., 2015). In addition, Marrero and Kader (2006) claim that the decrease of colour ( $\mathrm{L}^{*}$ and $\mathrm{b}^{*}$ ) of fresh-cut pineapple during storage was due to the development of translucency.

Fruit firmness is an important criterion that influences the quality and freshness of the fruit. Fresh-cut pineapple treated with $15 \mathrm{~mL}$ $\mathrm{N}_{2}$ tends to have a higher firmness value and is indicated as the most rigid and crisp among the treatments (Table 2). In contrast, Benitez et al.
(2012) reported that the loss in texture might be a consequence of a decrease in cell wall turgor and lower enzymatic activity, as well as lower cell juice loss (Rocculi et al., 2005) caused by the $\mathrm{N}_{2}$ gas throughout the storage period. The enzymes that are responsible for tissue softening are pectinesterase, polygalacturonase and beta-galactosidase (Rocculi et al., 2005). In addition, Budu and Joyce (2005) claimed that high concentration of $\mathrm{CO}_{2}$ stimulate rapid senescence by causing physiological injury in the cellular compartment and sap leakage in the cell wall. A similar result was observed by Deng et al. (2007), in which the fumigation of $\mathrm{CO}_{2}$ in Kyoho grapes was able to reduce the activity of cellulase, polygalacturonase and peroxidase. Another possible reason for the loss in texture is the processing of fruits by cutting and peeling (Saltveit, 2000). The hydrolysis of cell wall components during translucency development has also contributed to the loss in texture in papaya (Rivera et al., 2005; Karakurt \& Huber, 2003), mango and pineapple (Martinez et al., 2002).

In the stage of minimally processed product development, storage conditions in maintaining desirable sensory characteristic while also preserve nutritive value include SSC and TA of the fruit. In the present study, SSC and TA (Table 2) of all treated fruit resulted in non-significant differences after the fumigation of $\mathrm{N}_{2}$ and $\mathrm{CO}_{2}$ gases. Similarly, Lau et al. (1997) reported that $20 \mathrm{~mL} \mathrm{CO}$ treatment had no influential effect on SSC of McIntosh apple (Lau et al., 1997). El-Rayes (2009) also found that $\mathrm{CO}_{2}$ and $\mathrm{N}_{2}$ had no effect on SSC. Similarly, Crisosto et al. (2002) reported that the application of high levels of $\mathrm{CO}_{2}$ did not affect TA of seedless grapes. Meanwhile, the SSC value in tomato is lower when exposed to higher levels of $\mathrm{CO}_{2}$ as the ripening rate is inhibited by high $\mathrm{CO}_{2}$ concentration (Ali \& Thompson, 1998). Therefore, the production of sugars, organic acids and other substances, which contributes to the TSS value of tomato, was inhibited. Hobson and Davies (1971) reported that higher levels of $\mathrm{CO}_{2}$ prevented the production of sugars, organic acids and other chemicals, which are 
the main substance of SSC. In addition, the decrease of SSC, TA and ascorbic acid could be due to the damage of the cell structure caused by the cutting process. Moreover, the increase in metabolic activity also accelerates the decline of these quality attributes (Hodges \& Toiyonen, 2008). The qualities of SSC and TA are closely related to the loss of ascorbic acid.

Ascorbic acid is a natural antioxidant compound that is highly susceptible to degradation (Sindumathi et al., 2017). Based on Table 2, pineapple treated with different concentrations of $\mathrm{N}_{2}$ and $\mathrm{CO}_{2}$ alone or in combination did not significantly affect ascorbic acid concentrations. In contrast, Wu et al. (2012) reported that the ascorbic acid content decreased with the increase in storage period, which is due to the degradation of ascorbic acid through oxidative processes. Moreover, enzymes, like ascorbate oxidase, might cause bruising of the tissue due to the amount of ascorbic acid in the presence of $\mathrm{O}_{2}$.

Table 1: The effects of nitrogen and carbon dioxide gases on the flesh colour attributes of fresh-cut pineapples

\begin{tabular}{|c|c|c|c|c|c|}
\hline Treatment/Day & 0 & 3 & 6 & 9 & 12 \\
\hline \multicolumn{6}{|l|}{ Lightness $\left(\mathrm{L}^{*}\right)$} \\
\hline $0 \mathrm{~mL}$ & $73.41^{\mathrm{a}}$ & $73.48^{\mathrm{a}}$ & $71.12^{\mathrm{a}}$ & $69.99^{\mathrm{a}}$ & $67.83^{\mathrm{a}}$ \\
\hline $15 \mathrm{~mL} \mathrm{~N}_{2}$ & $60.46^{\mathrm{a}}$ & $72.92^{\mathrm{a}}$ & $73.55^{\mathrm{a}}$ & $71.48^{\mathrm{a}}$ & $69.48^{\mathrm{a}}$ \\
\hline $25 \mathrm{~mL} \mathrm{~N}_{2}$ & $71.64^{\mathrm{a}}$ & $71.38^{\mathrm{a}}$ & $71.36^{\mathrm{a}}$ & $70.62^{\mathrm{a}}$ & $67.02^{\mathrm{a}}$ \\
\hline $15 \mathrm{~mL} \mathrm{CO}_{2}$ & $73.06^{\mathrm{a}}$ & $72.20^{\mathrm{a}}$ & $71.43^{\mathrm{a}}$ & $66.64^{\mathrm{a}}$ & $67.46^{\mathrm{a}}$ \\
\hline $25 \mathrm{~mL} \mathrm{CO}_{2}$ & $74.71^{\mathrm{a}}$ & $71.46^{\mathrm{a}}$ & $73.19^{\mathrm{a}}$ & $70.39^{\mathrm{a}}$ & $69.06^{\mathrm{a}}$ \\
\hline $15 \mathrm{~mL} \mathrm{~N}_{2}+15 \mathrm{~mL} \mathrm{CO}_{2}$ & $75.27^{\mathrm{a}}$ & $69.62^{\mathrm{a}}$ & $70.37^{\mathrm{a}}$ & $67.31^{\mathrm{a}}$ & $67.34^{\mathrm{a}}$ \\
\hline $25 \mathrm{~mL} \mathrm{~N}_{2}+25 \mathrm{~mL} \mathrm{CO}_{2}$ & $71.74^{\mathrm{a}}$ & $72.35^{\mathrm{a}}$ & $72.98^{\mathrm{a}}$ & $69.73^{\mathrm{a}}$ & $67.55^{\mathrm{a}}$ \\
\hline $\mathrm{HSD}_{0.05}$ & $25.95^{\text {ns }}$ & $4.64^{\mathrm{ns}}$ & $7.29^{\mathrm{ns}}$ & $8.90^{\mathrm{ns}}$ & $6.42^{\mathrm{ns}}$ \\
\hline \multicolumn{6}{|l|}{ Chromaticity a* } \\
\hline $0 \mathrm{~mL}$ & $-3.52^{\mathrm{a}}$ & $-2.70^{a}$ & $-2.06^{\mathrm{a}}$ & $-0.36^{\mathrm{a}}$ & $1.72^{\mathrm{a}}$ \\
\hline $15 \mathrm{~mL} \mathrm{~N}_{2}$ & $-3.29^{\mathrm{a}}$ & $-2.81^{a}$ & $-2.42^{a}$ & $-1.21^{\mathrm{a}}$ & $0.59^{\mathrm{a}}$ \\
\hline $25 \mathrm{~mL} \mathrm{~N}_{2}$ & $-3.83^{\mathrm{a}}$ & $-3.03^{a}$ & $-1.69^{a}$ & $1.943^{\mathrm{a}}$ & $4.76^{\mathrm{a}}$ \\
\hline $15 \mathrm{~mL} \mathrm{CO}_{2}$ & $-3.89^{\mathrm{a}}$ & $-2.89^{a}$ & $-1.08^{a}$ & $-0.27^{\mathrm{a}}$ & $3.83^{\mathrm{a}}$ \\
\hline $25 \mathrm{~mL} \mathrm{CO}_{2}$ & $-3.45^{a}$ & $-2.88^{a}$ & $-2.06^{a}$ & $0.23^{\mathrm{a}}$ & $1.85^{\mathrm{a}}$ \\
\hline $15 \mathrm{~mL} \mathrm{~N}_{2}+15 \mathrm{~mL} \mathrm{CO}_{2}$ & $-4.63^{a}$ & $-2.66^{a}$ & $-1.52^{a}$ & $1.16^{\mathrm{a}}$ & $4.38^{\mathrm{a}}$ \\
\hline $25 \mathrm{~mL} \mathrm{~N}_{2}+25 \mathrm{~mL} \mathrm{CO}_{2}$ & $-3.58^{a}$ & $-2.80^{a}$ & $-1.72^{\mathrm{a}}$ & $0.09^{\mathrm{a}}$ & $5.28^{\mathrm{a}}$ \\
\hline $\mathrm{HSD}_{0.05}$ & $2.45 \mathrm{~ns}$ & $1.09 \mathrm{~ns}$ & $1.96 \mathrm{~ns}$ & $3.26 \mathrm{~ns}$ & $3.59 \mathrm{~ns}$ \\
\hline \multicolumn{6}{|l|}{ Chromaticity b* } \\
\hline $0 \mathrm{~mL}$ & $30.30^{\mathrm{a}}$ & $23.26^{\mathrm{a}}$ & $25.53^{\mathrm{a}}$ & $26.06^{\mathrm{a}}$ & $21.80^{\mathrm{a}}$ \\
\hline $15 \mathrm{~mL} \mathrm{~N}_{2}$ & $30.44^{\mathrm{a}}$ & $26.12^{\mathrm{a}}$ & $24.69^{\mathrm{a}}$ & $25.18^{\mathrm{a}}$ & $19.98^{\mathrm{a}}$ \\
\hline $25 \mathrm{~mL} \mathrm{~N}_{2}$ & $27.01^{\mathrm{a}}$ & $23.51^{\mathrm{a}}$ & $23.91^{\mathrm{a}}$ & $23.51^{\mathrm{a}}$ & $22.87^{\mathrm{a}}$ \\
\hline $15 \mathrm{~mL} \mathrm{CO}_{2}$ & $28.82^{\mathrm{a}}$ & $20.48^{\mathrm{a}}$ & $26.41^{\mathrm{a}}$ & $22.73^{\mathrm{a}}$ & $24.25^{\mathrm{a}}$ \\
\hline $25 \mathrm{~mL} \mathrm{CO}_{2}$ & $26.76^{\mathrm{a}}$ & $23.78^{\mathrm{a}}$ & $20.44^{\mathrm{a}}$ & $25.89^{a}$ & $22.87^{\mathrm{a}}$ \\
\hline $15 \mathrm{~mL} \mathrm{~N}_{2}+15 \mathrm{~mL} \mathrm{CO}_{2}$ & $19.64^{\mathrm{a}}$ & $19.81^{\mathrm{a}}$ & $21.62^{\mathrm{a}}$ & $23.06^{\mathrm{a}}$ & $24.49^{\mathrm{a}}$ \\
\hline $25 \mathrm{~mL} \mathrm{~N}_{2}+25 \mathrm{~mL} \mathrm{CO}_{2}$ & $27.81^{\mathrm{a}}$ & $22.04^{\mathrm{a}}$ & $23.69^{\mathrm{a}}$ & $24.85^{\mathrm{a}}$ & $26.85^{\mathrm{a}}$ \\
\hline $\mathrm{HSD}_{0.05}$ & $9.26 \mathrm{~ns}$ & $7.86 \mathrm{~ns}$ & $10.92 \mathrm{~ns}$ & $7.72 \mathrm{~ns}$ & $6.08 \mathrm{~ns}$ \\
\hline
\end{tabular}




\begin{tabular}{lccccc}
\hline Hue angle $\left(\mathrm{h}^{\circ}\right)$ & & & & & \\
$0 \mathrm{~mL}$ & $-83.34^{\mathrm{a}}$ & $-83.38^{\mathrm{a}}$ & $-85.26^{\mathrm{a}}$ & $31.19^{\mathrm{a}}$ & $85.47^{\mathrm{a}}$ \\
$15 \mathrm{~mL} \mathrm{~N}_{2}$ & $-83.85^{\mathrm{a}}$ & $-83.78^{\mathrm{a}}$ & $-84.03^{\mathrm{a}}$ & $-87.29^{\mathrm{a}}$ & $88.41^{\mathrm{a}}$ \\
$25 \mathrm{~mL} \mathrm{~N}_{2}$ & $-81.91^{\mathrm{a}}$ & $-82.51^{\mathrm{a}}$ & $-85.93^{\mathrm{a}}$ & $85.55^{\mathrm{a}}$ & $78.29^{\mathrm{a}}$ \\
$15 \mathrm{~mL} \mathrm{CO}_{2}$ & $-82.18^{\mathrm{a}}$ & $-81.95^{\mathrm{a}}$ & $-87.51^{\mathrm{a}}$ & $-29.34^{\mathrm{a}}$ & $80.97^{\mathrm{a}}$ \\
$25 \mathrm{~mL} \mathrm{CO}_{2}$ & $-82.63^{\mathrm{a}}$ & $-83.08^{\mathrm{a}}$ & $-83.92^{\mathrm{a}}$ & $89.47^{\mathrm{a}}$ & $85.42^{\mathrm{a}}$ \\
$15 \mathrm{~mL} \mathrm{~N}_{2}+15 \mathrm{~mL} \mathrm{CO}_{2}$ & $-76.68^{\mathrm{a}}$ & $-82.25^{\mathrm{a}}$ & $-86.00^{\mathrm{a}}$ & $87.15^{\mathrm{a}}$ & $79.677^{\mathrm{a}}$ \\
$25 \mathrm{~mL} \mathrm{~N}_{2}+25 \mathrm{~mL} \mathrm{CO}_{2}$ & $-82.55^{\mathrm{a}}$ & $-82.52^{\mathrm{a}}$ & $-85.58^{\mathrm{a}}$ & $-30.18^{\mathrm{a}}$ & $79.14^{\mathrm{a}}$ \\
$\mathrm{HSD}_{0.05}$ & $5.545 \mathrm{~ns}$ & $3.49 \mathrm{~ns}$ & $6.09 \mathrm{~ns}$ & $183.68 \mathrm{~ns}$ & $7.5294 \mathrm{~ns}$ \\
\hline
\end{tabular}

$\mathrm{ns}=$ not significant $(\mathrm{p}>0.05), * *=$ very significant $(\mathrm{p}<0.05)$

Table 2: The effects of nitrogen and carbon dioxide gases on flesh firmness, soluble solids concentration, titratable acidity and ascorbic acid concentration of fresh-cut pineapples

\begin{tabular}{|c|c|c|c|c|c|}
\hline Treatment/Day & 0 & 3 & 6 & 9 & 12 \\
\hline \multicolumn{6}{|l|}{ Flesh firmness $(\mathrm{N})$} \\
\hline $0 \mathrm{~mL}$ & $3.078^{\mathrm{a}}$ & $2.95^{\mathrm{a}}$ & $3.37^{\mathrm{a}}$ & $2.00^{\mathrm{a}}$ & $1.95^{\mathrm{a}}$ \\
\hline $15 \mathrm{~mL} \mathrm{~N}_{2}$ & $3.276^{\mathrm{a}}$ & $1.84^{\mathrm{a}}$ & $2.11^{\mathrm{a}}$ & $2.47^{\mathrm{a}}$ & $2.47^{\mathrm{a}}$ \\
\hline $25 \mathrm{~mL} \mathrm{~N}_{2}$ & $2.815^{\mathrm{a}}$ & $3.49^{\mathrm{a}}$ & $2.56^{\mathrm{a}}$ & $1.95^{\mathrm{a}}$ & $2.37^{\mathrm{a}}$ \\
\hline $15 \mathrm{~mL} \mathrm{CO}_{2}$ & $4.368^{\mathrm{a}}$ & $2.73^{\mathrm{a}}$ & $2.57^{\mathrm{a}}$ & $2.26^{\mathrm{a}}$ & $2.24^{\mathrm{a}}$ \\
\hline $25 \mathrm{~mL} \mathrm{CO}_{2}$ & $3.437^{\mathrm{a}}$ & $3.13^{\mathrm{a}}$ & $2.59^{\mathrm{a}}$ & $2.11^{\mathrm{a}}$ & $2.05^{\mathrm{a}}$ \\
\hline $15 \mathrm{~mL} \mathrm{~N}_{2}+15 \mathrm{~mL} \mathrm{CO}_{2}$ & $4.247^{\mathrm{a}}$ & $2.58^{\mathrm{a}}$ & $2.66^{\mathrm{a}}$ & $2.13^{\mathrm{a}}$ & $2.19^{\mathrm{a}}$ \\
\hline $25 \mathrm{~mL} \mathrm{~N}_{2}+25 \mathrm{~mL} \mathrm{CO}_{2}$ & $4.749^{\mathrm{a}}$ & $2.20^{\mathrm{a}}$ & $3.34^{\mathrm{a}}$ & $1.87^{\mathrm{a}}$ & $2.22^{\mathrm{a}}$ \\
\hline $\mathrm{HSD}_{0.05}$ & $4.48 \mathrm{~ns}$ & $2.14 \mathrm{~ns}$ & $2.60 \mathrm{~ns}$ & $1.07 \mathrm{~ns}$ & $0.71 \mathrm{~ns}$ \\
\hline \multicolumn{6}{|c|}{ Soluble Solids Concentration (\%) } \\
\hline $0 \mathrm{~mL}$ & $7.86^{\mathrm{a}}$ & $9.00^{\mathrm{a}}$ & $9.50^{\mathrm{a}}$ & $12.00^{\mathrm{a}}$ & $8.76^{\mathrm{a}}$ \\
\hline $15 \mathrm{~mL} \mathrm{~N}_{2}$ & $9.06^{\mathrm{a}}$ & $9.66^{\mathrm{a}}$ & $10.50^{\mathrm{a}}$ & $10.73^{\mathrm{a}}$ & $10.03^{\mathrm{a}}$ \\
\hline $25 \mathrm{~mL} \mathrm{~N}_{2}$ & $7.33^{\mathrm{a}}$ & $9.66^{\mathrm{a}}$ & $10.10^{\mathrm{a}}$ & $8.86^{\mathrm{a}}$ & $9.66^{\mathrm{a}}$ \\
\hline $15 \mathrm{~mL} \mathrm{CO}_{2}$ & $9.40^{\mathrm{a}}$ & $12.00^{\mathrm{a}}$ & $11.10^{\mathrm{a}}$ & $11.30^{\mathrm{a}}$ & $10.06^{\mathrm{a}}$ \\
\hline $25 \mathrm{~mL} \mathrm{CO}_{2}$ & $9.20^{\mathrm{a}}$ & $11.00^{\mathrm{a}}$ & $10.66^{\mathrm{a}}$ & $10.00^{\mathrm{a}}$ & $8.76^{\mathrm{a}}$ \\
\hline $15 \mathrm{~mL} \mathrm{~N}_{2}+15 \mathrm{~mL} \mathrm{CO}_{2}$ & $9.53^{\mathrm{a}}$ & $12.00^{\mathrm{a}}$ & $9.40^{\mathrm{a}}$ & $11.33^{\mathrm{a}}$ & $9.70^{\mathrm{a}}$ \\
\hline $25 \mathrm{~mL} \mathrm{~N}_{2}+25 \mathrm{~mL} \mathrm{CO}_{2}$ & $9.53^{\mathrm{a}}$ & $11.33^{\mathrm{a}}$ & $9.50^{\mathrm{a}}$ & $10.70^{\mathrm{a}}$ & $9.76^{\mathrm{a}}$ \\
\hline $\mathrm{HSD}_{0.05}$ & $1.73 \mathrm{~ns}$ & $4.34 \mathrm{~ns}$ & $4.41 \mathrm{~ns}$ & $2.98 \mathrm{~ns}$ & $3.14 \mathrm{~ns}$ \\
\hline \multicolumn{6}{|c|}{ Titratable Acidity ( $\%$ Citric Acid) } \\
\hline $0 \mathrm{~mL}$ & $3.76^{\mathrm{a}}$ & $6.60^{\mathrm{a}}$ & $6.00^{\mathrm{a}}$ & $6.23^{\mathrm{a}}$ & $4.80^{\mathrm{a}}$ \\
\hline $15 \mathrm{~mL} \mathrm{~N}_{2}$ & $4.36^{\mathrm{a}}$ & $5.43^{\mathrm{a}}$ & $7.93^{\mathrm{a}}$ & $6.70^{\mathrm{a}}$ & $6.46^{\mathrm{a}}$ \\
\hline $25 \mathrm{~mL} \mathrm{~N}_{2}$ & $3.93^{\mathrm{a}}$ & $6.00^{\mathrm{a}}$ & $6.23^{\mathrm{a}}$ & $6.26^{\mathrm{a}}$ & $5.46^{\mathrm{a}}$ \\
\hline $15 \mathrm{~mL} \mathrm{CO}_{2}$ & $3.66^{\mathrm{a}}$ & $6.06^{\mathrm{a}}$ & $6.66^{\mathrm{a}}$ & $5.66^{\mathrm{a}}$ & $5.70^{\mathrm{a}}$ \\
\hline $25 \mathrm{~mL} \mathrm{CO}_{2}$ & $4.83^{\mathrm{a}}$ & $5.03^{\mathrm{a}}$ & $6.80^{\mathrm{a}}$ & $7.90^{\mathrm{a}}$ & $5.66^{\mathrm{a}}$ \\
\hline $15 \mathrm{~mL} \mathrm{~N}_{2}+15 \mathrm{~mL} \mathrm{CO}_{2}$ & $4.50^{\mathrm{a}}$ & $5.93^{\mathrm{a}}$ & $6.33^{\mathrm{a}}$ & $5.90^{\mathrm{a}}$ & $4.96^{\mathrm{a}}$ \\
\hline $25 \mathrm{~mL} \mathrm{~N}_{2}+25 \mathrm{mLCO}_{2}$ & $4.16^{\mathrm{a}}$ & $7.36^{\mathrm{a}}$ & $5.93^{a}$ & $6.53^{\mathrm{a}}$ & $4.43^{\mathrm{a}}$ \\
\hline $\mathrm{HSD}_{0.05}$ & $2.11 \mathrm{~ns}$ & $2.35 \mathrm{~ns}$ & $3.30 \mathrm{~ns}$ & $2.93 \mathrm{~ns}$ & $2.34 \mathrm{~ns}$ \\
\hline
\end{tabular}




\begin{tabular}{|c|c|c|c|c|c|}
\hline \multicolumn{6}{|c|}{ Ascorbic Acid Concentration (mg/g FW) } \\
\hline $0 \mathrm{~mL}$ & $2.32^{\mathrm{a}}$ & $1.15^{\mathrm{a}}$ & $1.82^{\mathrm{a}}$ & $1.32^{\mathrm{a}}$ & $1.22^{\mathrm{a}}$ \\
\hline $15 \mathrm{~mL} \mathrm{~N}_{2}$ & $2.51^{\mathrm{a}}$ & $0.98^{\mathrm{a}}$ & $1.70^{\mathrm{a}}$ & $2.16^{\mathrm{a}}$ & $1.80^{\mathrm{a}}$ \\
\hline $25 \mathrm{~mL} \mathrm{~N}_{2}$ & $2.00^{\mathrm{a}}$ & $1.07^{\mathrm{a}}$ & $1.55^{\mathrm{a}}$ & $1.85^{\mathrm{a}}$ & $1.47^{\mathrm{a}}$ \\
\hline $15 \mathrm{~mL} \mathrm{CO}_{2}$ & $2.01^{\mathrm{a}}$ & $1.18^{\mathrm{a}}$ & $2.02^{\mathrm{a}}$ & $1.74^{\mathrm{a}}$ & $1.48^{\mathrm{a}}$ \\
\hline $25 \mathrm{~mL} \mathrm{CO}_{2}$ & $1.82^{\mathrm{a}}$ & $1.24^{\mathrm{a}}$ & $1.56^{\mathrm{a}}$ & $2.18^{\mathrm{a}}$ & $1.82^{\mathrm{a}}$ \\
\hline $15 \mathrm{~mL} \mathrm{~N}_{2}+15 \mathrm{~mL} \mathrm{CO}_{2}$ & $2.36^{\mathrm{a}}$ & $1.28^{\mathrm{a}}$ & $1.93^{\mathrm{a}}$ & $1.69^{\mathrm{a}}$ & $1.33^{\mathrm{a}}$ \\
\hline $25 \mathrm{~mL} \mathrm{~N}_{2}+25 \mathrm{~mL} \mathrm{CO}_{2}$ & $2.11^{\mathrm{a}}$ & $1.36^{\mathrm{a}}$ & $2.21^{\mathrm{a}}$ & $1.33^{\mathrm{a}}$ & $1.31^{\mathrm{a}}$ \\
\hline HSD0.05 & $0.81 \mathrm{~ns}$ & $0.43 \mathrm{~ns}$ & $1.11 \mathrm{~ns}$ & $0.92 \mathrm{~ns}$ & $1.21 \mathrm{~ns}$ \\
\hline
\end{tabular}

ns $=$ not significant $(\mathrm{p}>0.05), * *=$ very significant $(\mathrm{p}<0.05)$

Sensory assessment is related to the characteristics of the product and consumer preference (Costell, 2002). A total of 30 panellists were randomly chosen for the sensory evaluation. Based on the sensory evaluations, all the attributes, such as colour, aroma, texture, sweetness, sourness, the tingling and prickling sensations, and overall acceptance, were not affected by the different gas fumigations. Appearance and colour play important roles in the quality and freshness of fresh-cut pineapple. Most of the panellist preferred the colour attribute of the control, $25 \mathrm{~mL} \mathrm{CO}_{2}$ and $25 \mathrm{~mL} \mathrm{CO}_{2}$ and $\mathrm{N}_{2}$ applications. Similarly, the $\mathrm{CO}_{2}$ reduced the colour in fresh-cut cantaloupe and honeydew melon (Marrero \& Kader, 2001). However, the results showed that the prickling and tingling sensations were less preferred by the panellists. Generally, the application of high levels of $\mathrm{CO}_{2}$ could shift the aerobic metabolism to anaerobic and induce the accumulation of fermentative volatiles, like ethanol and lactic acid (Teles et al., 2014). This changes in the metabolism cause alterations in the aroma and produce off flavours in the fruit. According to Ares et al. (2009), the fruit starts to decay and ferment as the storage period increases. However, the increase in ethanol in this experiment did not affect consumer acceptance as most of the panellists still preferred all the attributes, except sourness.

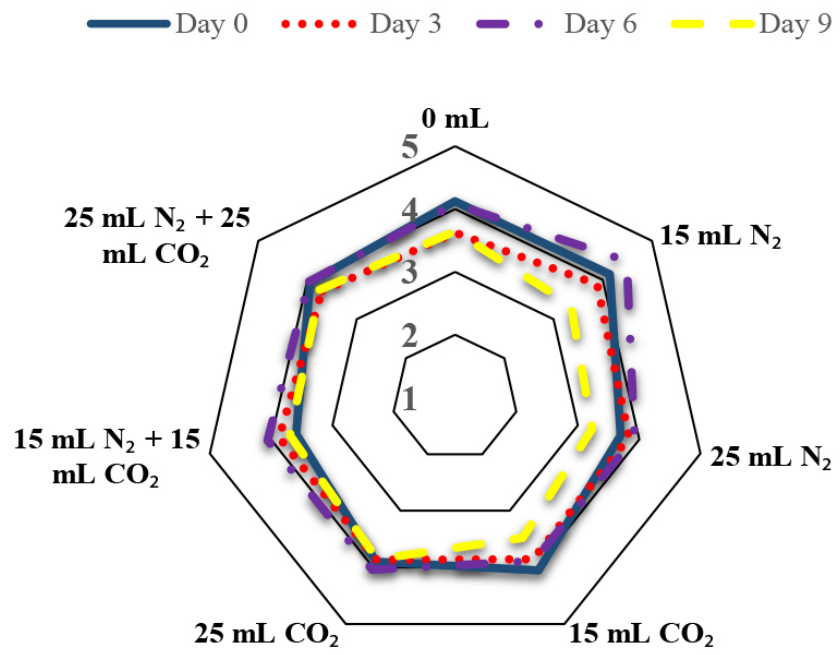

Figure 4: The effects of different volumes of nitrogen and carbon dioxide gases on the overall acceptability attributes of fresh-cut pineapple. The vertical bars represent Tukey at $\mathrm{P} \geq 0.05$. (HSD value $\mathrm{Day} 0=0.61$,

$$
\text { Day3 }=0.86 \text {, Day6 }=0.61 \text {, Day9 }=1.05 \text { ) }
$$




\section{Conclusion}

$\mathrm{N}_{2}$ and $\mathrm{CO}_{2}$ gases were not effective in reducing bromelain enzyme activity in Morris pineapple, as well as the prickling and tingling sensations it brings when consumed. Similarly, all of the postharvest attributes were also not affected with both gases, either alone or in combination. On top of that, the panellists mostly preferred the taste, which might be due to the ripening condition of the fruit. For further study, it is recommended that different gases are used to effectively reduce the prickling and tingling sensations. Other than that, other chemicals and plant growth hormones could be used.

\section{Acknowledgements}

The authors wish to thank Universiti Malaysia Terengganu for the financial support and the staff members of Postharvest Technology Laboratory for their kind help.

\section{References}

Alothman, M., Kaur, B., Fazilah, A., Bhat, R., \& Karim, A. A. (2010). Ozonedinducedchanges of antioxidant of fresh-cut fropical fruits. Innovative of Food Science Emergence Technology, 11, 666-671

Aisyah, A. H., Muhammad, F. M. H., Wahizatul, A. A., \& Wan, Z. W. S. (2018). Effects of different storage temperatures on physicochemical characteristics and quality of melon manis Terengganu (Cucumis melo var. Inodorus cv. Manis Terengganu 1). Transaction of Malaysian Society of Plant Physiology, 25, 183 - 191.

AOAC. (2004). Official methods of analysis. 13th ed.Arlington: Association of Official Analytical Chemists. pp. 746.

Ares, G., Barrios, S., Lareo, C., \& Lema, P. (2009). Development of a sensory quality index for strawberries based on correlation between sensory data and consumer perception. Postharvest Biology and Technology, 52, 97-102.
Avallone, S., Guiraud, J.P., Brillouet, J.M., \& Teisson, C. (2003). Enzymatic browning and biochemical alterations in black spots of pineapple (Ananas comosus (L.) Merr.). Current Microbiology, 47, 113-118.

Ali, B., \& Thompson, A. K. (1998). Effects of short term high carbon dioxide treatment on tomato ripening. Turkish Journal of Agriculture and Foresty, 22, 405-410.

Benitez, S., Chiumenti, M., Sepilcre, F., Achaerandio, I., \& Pujola, M. (2012).

Modelling the effect of storage temperature on the respiration rate and texture of fresh cut pineapple. Journal of Food Engineering, 113, 527-533.

Bhui, K., Prasad, S., George, J., \& Shukla, Y. (2009). Bromelain inhibits COX-2

expression by blocking the activation of MAPK regulated NF-kappa B against skin tumor initiation triggering mitochondrial death pathway. Cancer Letter, 282(1), 167176.

Budu, A. S., \& Joyce, D. C. (2005). Effect of modified atmosphere packaging on the qualityof minimally processed cv. 'Smooth Cayenne' fruit. Journal of Horticultural Science and Biotechnology, 80, 193-198.

Carlier, J. D., Sousa, N. H., Santo. T. E., d'Eeckenbrugge, G. C., \& Leita, J. M. (2010). A genetic map of pineapple (Ananas comosus (L.) Merr.) including SCAR, CAPS,SSR and EST-SSR Markers. Molecular Breeding, 29, 245-260.

Costell, E., (2002). A comparison of sensory methods in quality control. Food Quality and Preference, 13, 341-353

Crisosto., C. I., Garner, D., \& Crisosto, G. (2002). High carbon dioxide atmospheres affect stored 'Thompson Seedless' Table Grapes. HortScience, 37(7), 1074-1078.

Deng, Y., Wu, Y., Li, Y. F., Yang, M. D., Shi, C. B., \& Zheng, C. J. (2007). Studies of postharvest berry abscission of 'Kyoho' table grapes during cold storage and high oxygen atmospheres. Postharvest Biology Technology, 43, 95-10. 
Ding, P., Siti Hajar, A. \& Hasanah, M. G. (2007). Changes in selected quality characteristics of minimally processes carambola (Averrhoa carambola L.) when treated with ascorbic acid. Journal of Science of Food and Agriculture, 87, 702- 709.

El-Rayes, D. A. (2009). Effect of carbon dioxide enriched atmosphere during cold storage on limiting antioxidant losses and maintaining quality of "Barhy" date fruit. Journal of King Abdulaziz University, 20(1), 3-22.

Gonzalez-Aguilar, G. A., Fortiz, J., Cruz, R., Baez, R., \& Wang, C. Y. (2000). Methyl jasmonate reduces chilling injury and maintains postharvest quality of mango fruit. Journal of Agricultural and Food Chemistry, 48(2), 515-519.

Hodges, D. M., \& Toivonen, P. M. A. (2008). Quality of fresh-cut fruits and vegetables as affected by exposure to abiotic stress. Postharvest Biology and Technology, 48, 155-162.

Hobson, G. E. \& Davies, J. N. (1971). The tomato. In The Biochemistry of Fruits and Their Products. Academic Press London and New York. 2, 437-482.

Hidayat, T., Farah, I. A., Kuppusamya, C., Azman, A. S., \& Alina, W. (2012). Molecular identification of malaysian pineapple cultivar based on internal transcribed spacer region. APCBEE Procedia, 4, 146-151.

Juan, L., Jinfeng, X., Jian, P., Mei, Ge., \& Kai, Z (2015). Identification of the main allergenic proteins in high hydrostatic pressure pineapple juice and assessing the influence of pressure on their allergenicity. International Journal of Food Properties, 18, 10, 2134-2144, DOI: 10.1080/10942912.2014.966386.

Khairi, A. N., Falah, M. A. F., Suyantohadi, A., Takahashi, \& N., Nishina, H., (2015). 'Effect of storagetemperatures on color of tomato fruit (Solanum lycopersicum Mill.) cultivated under moderate water stress treatment. Agriculture and Agricultural Science Procedia, 3, 178-183.

Karakurt, Y., \& Huber, D. J. (2003). Activities of several membrane and cell wall hydrolases, ethylene biosynthetic enzymes, and cell wall polyuronide degradation during low temperature storage of intact and freshcut papaya fruit. Postharvest Biology and Technology, 28, 219-229.

Lau, D., MacDonald, R. A., \& Looney, N. E. (1977). Response of British Colombia grown golden delicious apples to a prestorage high $\mathrm{CO}_{2}$ treatment. In Proceeding of the Second National Controlled Atmosphere Research Conference. 57 April. Michigan State University. USA. Pp: 175-18.

Gil, M. I., Castaner, M., Ferreres, F., Arte, F., Francisco, A., \& Barbera., T. (1998). Modified-atmosphere packaging of minimally processed Lollo Rosso (Lactuca sativa). Z Lebensm Unters Forsch, 206, 350354.

Marrero, A., \& Kader, A. A., (2001). Factors affecting the post-cutting life and quality of minimally processed pineapple. Acta Horticulturae, 553, 705- 706

Marrero, A., \& Kader, A. A. (2006). Optimal temperature and modified atmosphere for keeping quality of fresh-cut pineapples. Postharvest Biology and Technology, 39(2), 163-168.

Martinez, F.M., Harper, C., Perez, M.F., \& Chaparro, F. (2002). Modified atmospherepackaging of minimally processed mango and pineapple fruits. Journal of Food Science, 6(9), 3365-3371.

Malaysian Pineapple Industry Board. Retrieved from http://www.mpib.gov.my/kultivar/.

McGuire, R. G. (1992). Reporting of colour objective measurements. HortScience, 27, 1254-1255

Mohan, R., Sivakumar, V., Rangasamy, T., \& Muralidharan, C. (2016). Optimisation of bromelain enzyme extraction from pineapple (Ananas comosus) and 
Application in Process Industry. American Journal of Biochemistry and Biotechnology, 12(3), 188-195.

Qiuping, Z., \& Wenshui, X. (2007). Effect of 1-methylcyclopropene and/or chitosan coating treatments on storage life and quality maintenance of Indian jujube fruit. LWT - Food Science and Technology, 40, 404-411.

Rocculi, P., Romani, S., \& Dalla Rosa, M. (2005). Effect of MAP with argon and nitrous oxide on quality maintenance of minimally processed kiwifruit. Postharvest Bioliogy and Technology, 35, 319-328.

Rivera, L. J., Vasquez, O. F. A., Ayala, Z. J. F., Sotelo, M. R. R., \& Gonzalez, G. A. A. (2005). Cutting shape and storage temperature affect overall quality of freshcut papaya cv. 'Maradol'. Journal of Food Science, 70(7), 3432-3439.

SAS Institute Inc (1999) SAS Online Document. Version 8. Cary. North Carolina, USA.

Saltveit, M.E. 2000. Wound induced changes in phenolic metabolism and tissue browning are altered by heat shock. Postharvest Biology and Technology, 21, 61-69.

Salvador, A., Arnal, L., Monterde, A., \& Cuquerella, J. (2004). Reduction of chilling injury symptoms in persimmon fruit cv.Rojo Brillante by 1-MCP. Postharvest Biology and Technology, 33(3), 285-29.

Sayyari, M., Babalar, M. S., Kalantari, M. S., \& Valero, D. (2009). Effect of salicylic acid treatment on reducing chilling injury in stored pomegranates, Postharvest Biology and Technology, 53, 152-154.

Sayyari, M., Babalar, M., Kalantari, S., Martinez-Romero, D., Guillen, F., \& Serrano, M. (2011). Vapour treatments with methyl salicylate or methyl jasmonate alleviated chilling injury and enhanced antioxidant potential during postharvest storage of pomegranates. Food Chemistry, 124(3), 964-970.

Sindumathi, G., Amuha, S., \& Kavitha, V. (2017).
Impact of packaging materials onquality of fresh cut pineapple using biopreservative to ensure safety. International Journal Current Microbiology Application Science, 6(12),789-800.

Singh, S. P., Singh, Z., \& Swinny, E. E. (2009). Postharvest nitric oxide fumigation delays fruit ripening and alleviates chilling injury during cold storage of Japanese plums (Prunus salicina Lindell), Postharvest Biology and Technology, 53(3), 101-108.

Singleton, V., \& Rossi, J. (1965) Colorimetry of Total Phenolic Compounds with Phosphomolybdic-Phosphotungstic Acid Reagents. American Journal of Enology and Viticulture, 16, 144-158.

Tan, G. I., Aidilla, M., \& Wan, Z. W. S. (2017). Effects of different volumes of nitrogen gas fumigation on postharvest performances of fresh cut pineapple (Ananas comosus). Proceeding of international conference on food sovereignty and sustainable agriculture (FOSSA). Jember, 1st - 3rd August, 217-227.

Teles, C. S., Benedetti, B. C., Gubler, W. D., \& Crisoto, C. H. (2014). Prestorage application of $h \quad$ i $\quad g \quad h$ carbon dioxide combined with controlled atmosphere storage as a dual approach to control Brotrytiscinerea in organic "Flame Seedless: and "Crimson Seedless" table grapes. Postharvest Biology and Technology, 89, 32-39.

Thalip, A. A., Tong, P. S, \& Ng, C. (2015). The MD2 'Super Sweet' pineapple (Ananas comosus). UTAR Agriculture Science Journal, 1(4), 14-17.

Wan Z. W. S., \& Koh, S. Y. (2016). Effects of nitrogen gas fumigation on postharvest quality of minimally processed carambola (Averrhoa carambola L.) stored at low temperature. Malaysian Applied Biology, 46, 189-198.

Wu, Z. S., Zhang, M., \& Wang, S. J. (2012). Effects of high-pressure argon and nitrogen treatments on respiration, browning and 
antioxidant potential of minimally processed ineapples during shelf life. Journal of the Science of Food and Agriculture, 92, 22502259.

Yeoh, W. K., Ali, A., \& Forney, C. F. (2014). Effects of ozone on major antioxidants and microbial populations of fresh cut papaya. Postharvest Biology and Technology, 89, 56-58.
Yuris, A., \& Siow, L. F. (2014). A comparative study of the antioxidant properties ofthree pineapple (Ananas comosus L.) varieties. Journal of Food Studies, 3(1), 40-56.

Zhan, Z. G., \& Zhang, M. (2005). Effects of inert gases on enzyme activity and inspiration of cucumber. Journal of Food Biotechnology, 24, 16-18. 